\title{
IT Risk Management based on ISO 31000 For BRImo Application (BRI Mobile) as an Transaction Processing Information System
}

\author{
Fatma Wati, Sarmila Sari, \& Joy Nashar Utamajaya \\ Sistem Informasi, STMIK Borneo Internasional Balikpapan \\ Email: Fatmawati.18@stmik-borneo.ac.id
}

\begin{abstract}
BRImo application is a software support system owned by Bank bri in order to increase profits and provide maximum service to customers. With the BRImo application, it can make it easier for customers to register for new account openings and e-banking transactions anywhere without being limited by space and time. However, implementing information technology is not without risk, because banks are a highly regulated industry and must be carried out prudently. With the growing complexity of BRI's business activities and operations, the risks faced are also getting bigger. Threats that arise to operational activities can be triggered by various factors, both internal and external. Therefore, there is a need for risk management analysis on the BRImo Application using the ISO 31000 framework so that the possible risks that will occur can be minimized or eliminated by carrying out Risk Assessment and Risk Treatment. The results of this study are various possible risks in the identified application using a probability and impact matrix as well as the handling of the possible risks that exist. So that the results of this risk analysis can be used to help companies prevent, minimize risks, and treat these risks according to their priorities before the possibility of these risks hampering the company's performance.
\end{abstract}

Keywords: BRI Bank, BRImo Application, IT Risk Management, ISO 31000 Framework, Risk Assesment, And IT risk treatment

\section{Introduction}

The use of smartphones today is a very important need for society. The high number of public interest in the use of applications to facilitate human activities both in transactions and shopping online has made agencies, both government and private, compete to innovate to continue to improve their services through digital services. Based on data from the Ministry of Communication and Information (Kemenkominfo) states that internet or smartphone users in Indonesia reach 167 million people or about $89 \%$ of the total population of Indonesia [1].

The rapid growth of smartphone users in Indonesia has a positive impact on the business world, including the banking sector where the use of technology can make it easier for banks to provide better services to their customers by launching information technology- based banking transaction services, namely mobile banking. The m-banking service opens up opportunities for customers to conduct banking transactions via mobile devices or Personal Data Assistants (PDA).

Mobile banking is a banking service facility provided by the bank to customers to carry out various banking transactions through various features available on smartphones. The services contained in mobile banking consist of payments, history, transfers, and others. The use of mobile banking services on cellular phones allows customers to more easily carry out their banking activities without the limitations of space and time. With the mobile banking service, it is expected to provide convenience and benefits for customers in accessing the bank without having to come directly to the bank.

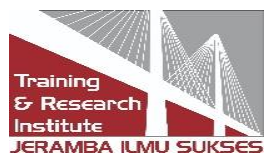


The current digital era has changed conventional services to digital. Digitization services not only facilitate customers with machines, but also make customers transact quickly, frictionless, and provide satisfaction (customer experience). One of the Indonesian banks that has implemented mobile banking-based digital services is Bank Bri. Bank Bri realizes that the role of information technology is very important and if they don't keep up with the times, they will be displaced by other banks that first implement digital m-banking services, especially considering that the pattern of people's life needs has also changed.

Bank Rakyat Indonesia (BRI) as one of the state-owned banks is very concerned about the times in improving the quality of banking services to customers. this is proven by presenting the latest service technology innovation, namely BRImo or BRI Mobile which has a security system that is better than BRI Mobile because this application applies user interface (UI) and user experience (UX) technology. BRImo is the latest mobile application development from the previous BRI Mobile application and has been used by 2.2 million customers in just 8 months since it was launched in February 2019 ago[2]. BRImo is a media for finding new customers, especially millennials who use smartphones a lot.

The BRImo or Bri Mobile application has several advantages that are offered to customers in facilitating e-banking transactions such as BRImo providing convenience in opening new accounts with the application, customers can view account mutations without using a passbook for the last 1 year of use which can be saved via PDF file and can be shared via Whatsapp chat, login with finger print/face recognition, and have access to promo info. The BRImo application has also combined the functions of mobile banking, internet banking, and electronic money (Tbank) in one application with a more complete and attractive transaction menu.

However, every application that is an important asset for the company must have the possibility of risks that can interfere and make the application not run optimally, and the BRImo application is no exception. Risk is the possibility of an event occurring that can result in a loss for the company. Tugiman (2009), defines risk as an adverse event or not achieving the expected goals [3]. Risk is related to uncertainty. This uncertainty occurs because of the lack or unavailability of information regarding what will happen. In a company, adverse uncertainty is called risk. The risk that is often an obstacle in the BRImo application can be triggered by various factors, both internal and external.

In identifying risk management in the BRImo application at BRI Indonesia, the appropriate guideline to be used in this research is to use ISO 31000 . ISO 31000 is a standard related to risk management issued on November 13, 2009 by the International Organization for Standardization (ISO). This standard is intended to be applicable and adapted for all types of organizations by providing a generic structure and guidelines applicable to all operations related to risk management. According to ISO 31000, the risk management of an organization must follow 11 basic principles in order to be implemented effectively. The following is a description of these principles. Namely: Risk management creates added value, Risk management is an integral part of organizational processes, Risk management is part of decision making, Risk management explicitly addresses uncertainty. Risk management is systematic, structured, and timely, Risk management is based on the best available information, Risk management is tailored to the needs, Risk management takes into account human and cultural factors, Risk management is transparent and inclusive, Risk management is dynamic, iterative, and responsive to change, Risk management facilitates continuous improvement and development of the organization[4].

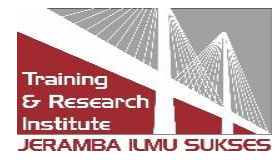




\section{Literature Review}

\subsection{Previous Reasearch}

Research by Aprilia Rahmawati in 2019 regarding Information Technology Risk Analysis Using ISO 31000 on iTop Applications. The research carried out has the aim of documenting the possible risks that arise, the level of risk impact and recommendations for risk treatment that can be carried out. From the results of research conducted on the iTop application, it resulted in a risk analysis, namely 21 possible risks that interfere with the performance of the iTop application, 8 possible risks included in the medium level of risk, and 17 possible risks included in the low level of risk [5].

Stefan Agustinus also conducted research on Information Technology Risk Analysis Using ISO 31000 in the Human Resources Management System Program in 2017. This study aims to document the risks faced and actions that can be taken to minimize risks to the HRMS program. The research that has been done has resulted in 26 possible risks, 2 risks having a high level of risk, 18 possible risks having a medium level of risk, and 6 possible risks having a low level of risk.[6]

In 2017 research using ISO 31000 was also carried out by Zainal Putra, Syafruddin Chan, and Moenawar IHA, the research was conducted at PDAM Tirta Meulaboh, from the research conducted, it was found that there are potential risks which if not handled immediately can affect the performance of the company. company and even the continuity of the company [7].

Based on these studies, it can be seen that there is a relationship with the research that will be carried out by the author, namely risk analysis using ISO 31000 which aims to identify possible risks that arise, the impact of these risks, risk levels, and risk treatment of existing risks.

\subsection{Basic Theory}

The International Organization for Standardization (ISO) 31000: 2009 Risk Management Principles and Guidelines is an international standard created with the aim of being used as risk management principles and guidelines. ISO 31000 provides principles, frameworks, and risk management that can be used by various companies in analyzing an existing risk. In conducting research, the method to find data and information is to conduct interviews with resource persons from IT staff or BRI bank employees, then the existing data is processed and later analyzed in accordance with the ISO 31000 framework.

In the first stage to analyze is done by risk assessment. The risk assessment process is divided into 3 stages which are carried out to assess a risk, namely the risk identification stage, risk analysis, then the risk evaluation stage. At the risk assessment stage, the risk criteria are determined that may occur and which will affect the performance of a company in its efforts to achieve a goal, then in the second stage of risk management is risk treatment, at this stage the researcher selects the possible risks, reduces and eliminate the impact of risks that may occur in a company[8]. 


\section{Research Method}

\subsection{Risk Management}

FIGURE 1. Risk Management (ISO 31000)

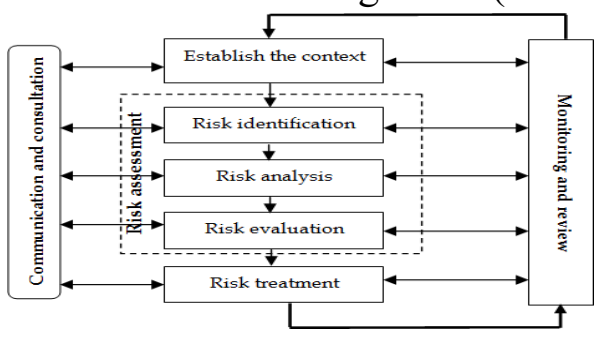

International Organization for Standardization (ISO) 31000 as shown in figure 1 below, is a standard that was developed with the aim of providing universal risk management principles and guidelines. In the International Organization for Standardization (ISO 31000:2009) there are 2 stages in the risk management process. The first stage is risk assessment, which is the process of determining the risks that have the potential to prevent the company from achieving its business goals. In the risk assessment stage, there are 3 processes, namely risk identification, risk analysis, and risk evaluation.

1) Risk Identification: At this stage includes identification of risks that may occur in an activity. Identification carried out accurately and completely is vital in risk management. It is an important aspect of risk management. Techniques that can be used are interviews, surveys, historical information and others.

2) Risk Analysis (Risk Analyst): This stage looks at the potential risk, how much damage occurs in the risk. The probability of an event is very subjective and is based more on experience and reason

3) Risk Evaluation: At this stage, it is carried out to determine risk management by comparing the level of risk to a predetermined standard. The purpose of risk evaluation is to know the priority level from high to low and to know which level of risk must be followed up and which are monitored.

The next stage is Risk Treatment. This stage is an effort to complete options that can reduce or even eliminate the possibility and impact of the risks that occur and apply treatment.

\subsection{Methodology}

The method used in this study uses a qualitative method which is carried out by identifying risks to determine the potential risks that exist in the BRImo application. The qualitative method chosen aims to explore and understand the meaning that comes from social or humanitarian problems. In the qualitative research process, things are done such as asking questions to resource persons, collecting specific data from the field and resource persons.

The research was conducted by conducting interviews with IT staff or BRI bank, Tbk employees by asking various questions about the function of the BRImo system, what data and features are in the BRImo system, what possible risks can occur in the BRImo application, how to do it. overcome the risks that arise in the BRImo application, then the data needed focuses on the BRImo system used by the company to run its business.

\section{Findings and Discussions}




\subsection{Risk Assessment}

The risk assessment stage is the first stage carried out in research in accordance with the ISO 31000 risk management analysis guidelines. This stage is used in assessing the BRImo application which consists of 3 processes carried out namely risk identification, risk analysis, and risk evaluation. These three processes must be passed to go to the next stage.

\subsubsection{Risk Identification}

a. Identify BRImo Application Assets

The first process in the risk assessment stage is the process of risk identification or asset identification related to the BRImo application which is carried out through an interview process with IT Operation Support, Staff Manager, and employees at the BRI Bank,Tbk. At this stage, identification of assets from data, software to hardware related to the BRImo application is carried out.

TABLE 1. Identification of Assets in the BRImo Application

\begin{tabular}{|l|l|}
\hline \multicolumn{1}{|c|}{$\begin{array}{c}\text { Information } \\
\text { System } \\
\text { Components }\end{array}$} & \multicolumn{1}{c|}{ BRImo Application Assets } \\
\hline Data & Customer Data, Asset Data \\
\hline Software & BRImo app \\
\hline Hardware & $\begin{array}{l}\text { Personal Computer (PC), Server Database, Server Web } \\
\text { Service }\end{array}$ \\
\hline
\end{tabular}

b. BRImo Application Risk Identification

After identifying the assets associated with the BRImo application, the next thing that needs to be identified is the possible risks surrounding the BRImo application. The causes of risk can arise from several factors, these factors include the environment or nature, humans, systems and infrastructure. The following is Table 2 identification of possible risk

TABLE 2. Identification of possible risks

\begin{tabular}{|l|l|l|}
\hline \multicolumn{1}{|c|}{$\begin{array}{c}\text { Source of } \\
\text { Risk }\end{array}$} & \multicolumn{1}{|c|}{$\begin{array}{c}\text { Risk } \\
\text { Code }\end{array}$} & \multicolumn{1}{c|}{ Possibe Risk } \\
\hline \multirow{4}{*}{$\begin{array}{l}\text { Nature or } \\
\text { Environment }\end{array}$} & R01 & Flood \\
\cline { 2 - 4 } & R02 & Fire \\
\cline { 2 - 4 } & R03 & Earthquake \\
\cline { 2 - 4 } & R04 & Lightning \\
\hline \multirow{4}{*}{ Human } & R05 & Application can't run \\
\cline { 2 - 4 } & R06 & $\begin{array}{l}\text { Damage caused by human activities } \\
\text { (cybercrime and vandalism) }\end{array}$ \\
\cline { 2 - 4 } & R07 & Information accessed by unauthorized parties \\
\hline
\end{tabular}




\begin{tabular}{|c|c|c|}
\hline 7 & \multicolumn{2}{|r|}{$\begin{array}{r}\text { International Journal of information Systems and Informatics } \\
\text { e-ISSN 2746-1378 } \\
\text { Vol. 2, No.4 December } 2021\end{array}$} \\
\hline & R08 & Error Input data in the application \\
\hline & R09 & Device or data theft \\
\hline & $\mathrm{R} 10$ & The appearance of the application is not user friendly \\
\hline \multirow{10}{*}{$\begin{array}{l}\text { System and } \\
\text { infrastructure }\end{array}$} & R11 & Server Down \\
\hline & $\mathrm{R} 12$ & Full Memory \\
\hline & R13 & Bug In System or Application \\
\hline & R14 & Hacking against the network \\
\hline & $\mathrm{R} 15$ & Virus Attack \\
\hline & R16 & Slow response system performance \\
\hline & R17 & Error when inputting data in the application \\
\hline & $\mathrm{R} 18$ & No periodic maintenance \\
\hline & R19 & Logout system automatically \\
\hline & $\mathrm{R} 20$ & Hardware Damage \\
\hline
\end{tabular}

From the results of the risk identification process, it was found that there were 20 possible risks originating from natural/environmental factors, humans, systems and infrastructure that could potentially affect the delay in the use of the BRImo application, Then the possible risks that have been identified are identified their impact on the company.

c. Identification of BRImo Application Risk Impacts

TABLE 3. Identification of risk impacts

\begin{tabular}{|c|c|c|}
\hline $\begin{array}{l}\text { Risk } \\
\text { Code }\end{array}$ & Possible Risk & Risk Impact \\
\hline R01 & Flood & The company's business activities are hampered. \\
\hline $\mathrm{R} 02$ & Fire & $\begin{array}{l}\text { The company's infrastructure is damaged and the } \\
\text { company's business activities are stopped }\end{array}$ \\
\hline $\mathrm{R} 03$ & Earthquake & $\begin{array}{l}\text { Damage to the Company's infrastructure and } \\
\text { hampered business activities }\end{array}$ \\
\hline R04 & Lightning & $\begin{array}{l}\text { Damage to Company infrastructure, lost network } \\
\text { Connection }\end{array}$ \\
\hline R05 & Application can't run & Slow down business performance, targets are not met \\
\hline R06 & $\begin{array}{l}\text { Damage caused by human } \\
\text { activities (cybercrime } \\
\text { and vandalism) }\end{array}$ & Financial loss/company data information \\
\hline
\end{tabular}




\begin{tabular}{|c|c|c|}
\hline R07 & $\begin{array}{l}\text { Information accessed by } \\
\text { unauthorized parties }\end{array}$ & $\begin{array}{l}\text { Data can be manipulated and then disseminated to the } \\
\text { public but does not match the existing real data. }\end{array}$ \\
\hline R08 & $\begin{array}{l}\text { Error Input data in } \\
\text { the application }\end{array}$ & The inputted data becomes invalid \\
\hline R09 & Device or data theft & $\begin{array}{l}\text { The company lost in terms of information and } \\
\text { financial terms. }\end{array}$ \\
\hline R10 & $\begin{array}{l}\text { The appearance of the } \\
\text { application is not user } \\
\text { friendly }\end{array}$ & $\begin{array}{l}\text { Application users or Bri customers have difficulty } \\
\text { operating the BRImo application }\end{array}$ \\
\hline R11 & Server Down & Unable to access BRImo and database. \\
\hline $\mathrm{R} 12$ & Full Memory & New customer incident failed to be accommodated. \\
\hline R13 & $\begin{array}{l}\text { Bug In System or } \\
\text { Application }\end{array}$ & Errors in system performance, causing system crashes \\
\hline R14 & $\begin{array}{l}\text { Hacking against the } \\
\text { Network }\end{array}$ & $\begin{array}{l}\text { Business activities are disrupted and hamper the } \\
\text { business performance of the Company }\end{array}$ \\
\hline $\mathrm{R} 15$ & Virus Attack & $\begin{array}{l}\text { Resulting in corrupt data or bugs in the BRIMO } \\
\text { Application }\end{array}$ \\
\hline R16 & $\begin{array}{l}\text { Slow response system } \\
\text { Performance }\end{array}$ & $\begin{array}{l}\text { Performance is not optimal, the achievement of } \\
\text { the Company's targets is not met }\end{array}$ \\
\hline R17 & $\begin{array}{l}\text { Error when inputting data in } \\
\text { the Application }\end{array}$ & $\begin{array}{l}\text { Targets are not met, hindering the business } \\
\text { performance of the company }\end{array}$ \\
\hline $\mathrm{R} 18$ & No periodic maintenance & Unable to determine the cause of the hardware failure \\
\hline R19 & $\begin{array}{l}\text { Logout system } \\
\text { Automatically }\end{array}$ & $\begin{array}{l}\text { Re-entering unsaved data, slowing down the business } \\
\text { workflow of the company }\end{array}$ \\
\hline $\mathrm{R} 20$ & Hardware Damage & $\begin{array}{l}\text { Inhibiting the process of operating the BRImo } \\
\text { Application }\end{array}$ \\
\hline
\end{tabular}

\subsubsection{Risk analysis}

The Risk Analysis is the second process or process after the completion of risk identification, which is the risk analysis process. The risk analysis process is the process of measuring risk by looking at two aspects, namely the possibility of how much damage occurs (impact) and how often the risk occurs (likelihood). The results of the risk analysis process can be used as suggestions in the risk evaluation process and in the process of managing existing risks. In this process there are two tables, namely the impact table and the likelihood table. Table . Likelihood 
criteria are in "Table 4" while the Impact table is in "Table 5"

TABLE 4.Likelihood Criteria

\begin{tabular}{|c|l|l|l|}
\hline \multicolumn{2}{|c|}{ Likelihood } & \multirow{2}{*}{ Information } & \multirow{2}{*}{ Frequency of occurrence } \\
\cline { 1 - 2 } Value & Criteria & & \\
\hline 1 & Rare & This risk almost never occurs & $>2$ tahun year \\
\hline 2 & Unlikely & This risk is rare & $1-2$ year \\
\hline 3 & Possible & This risk happens sometimes & $7-12$ months \\
\hline 4 & Likely & This risk often occurs & $4-6$ Months \\
\hline 5 & Certain & The risk is bound to happen & $1-3$ Months \\
\hline
\end{tabular}

The probability value in Table 4 . has 5 values, namely the first is Rare, Unlikely, Possible, Likely, and Certain. Rare is the smallest possible value and almost never occurs. The highest possible value is Certain, which is the risk that occurs most often.

TABLE 5. Risk Impact

\begin{tabular}{|c|c|c|}
\hline \multicolumn{2}{|c|}{ Impact } & \multirow[b]{2}{*}{ Information } \\
\hline Value & Criteria & \\
\hline 1 & Insignificant & Risk Does not interfere with company activities \\
\hline 2 & Minor & $\begin{array}{l}\text { The company's activities were slightly hampered but the } \\
\text { company's core activities were not disrupted. }\end{array}$ \\
\hline 3 & Moderate & $\begin{array}{l}\text { Causing disruption to business processes so that part of the } \\
\text { company's activities are hampered. }\end{array}$ \\
\hline 4 & Major & Inhibits almost all company activities \\
\hline 5 & Catastrophic & $\begin{array}{l}\text { The company's activities stopped because the business } \\
\text { processes experienced total disruption }\end{array}$ \\
\hline
\end{tabular}

The Impact Value table above also has 5 values, namely Insigificant, Minor, Moderate Major and Catastrophic. Insignificant is the lowest impact value and Catastrophic is the highest impact value because it greatly disrupts existing business activities. Risk does not interfere with company activities.

After the probability and impact values have been determined, the next step is to conduct a oneby-one assessment of the possible risks that exist in the BRImo application. The following is a breakdown of 20 possible risks from a risk assessment with Impact and Likelihood, which can be seen in "Table 6".

TABLE 6. Assessment of possible risks with likelihood and impact 


\begin{tabular}{|c|c|c|c|}
\hline $\begin{array}{l}\text { Risk } \\
\text { Code }\end{array}$ & Possible Risk & Likelihood & Impact \\
\hline R01 & Flood & 1 & 2 \\
\hline R02 & Fire & 1 & 2 \\
\hline R03 & Earthquake & 1 & 5 \\
\hline R04 & Lightning & 2 & 1 \\
\hline R05 & Application can't run & 3 & 3 \\
\hline R06 & $\begin{array}{l}\text { Damage caused by human activities (cybercrime } \\
\text { and vandalism) }\end{array}$ & 4 & 3 \\
\hline R07 & Information accessed by unauthorized parties & 3 & 2 \\
\hline R08 & Error Input data in the application & 4 & 1 \\
\hline R09 & Device or data theft & 2 & 3 \\
\hline R10 & $\begin{array}{l}\text { The appearance of the application is not user } \\
\text { friendly }\end{array}$ & 2 & 1 \\
\hline R11 & Server Down & 5 & 5 \\
\hline R12 & Full Memory & 2 & 3 \\
\hline R13 & Bug In System or Application & 4 & 3 \\
\hline R14 & Hacking against the network & 1 & 2 \\
\hline $\mathrm{R} 15$ & Virus Attack & 3 & 5 \\
\hline R16 & Slow response system performance & 5 & 3 \\
\hline R17 & Error when inputting data in the application & 4 & 2 \\
\hline R18 & No periodic maintenance & 3 & 5 \\
\hline R19 & Logout system automatically & 4 & 2 \\
\hline $\mathrm{R} 20$ & Hardware Damage & 3 & 4 \\
\hline
\end{tabular}

\subsubsection{Risk evaluation}

The last process to complete the risk assessment stage is the risk evaluation process. In this process, a reference is used in the form of a risk evaluation matrix. Where in the matrix is divided into 3 risk levels, namely low, medium and high. Possible risks that have been determined by the likelihood value and impact value in the previous process will be differentiated again according to the existing matrix. Table 7 has mapped risk levels based on likelihood and impact

TABLE 7. Risk Evaluation Matrix 


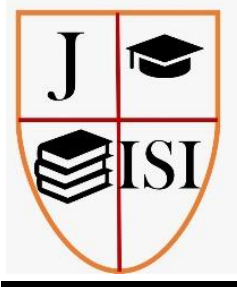

International Journal of information Systems and Informatics

e-ISSN 2746-1378

Vol. 2, No.4 December 2021

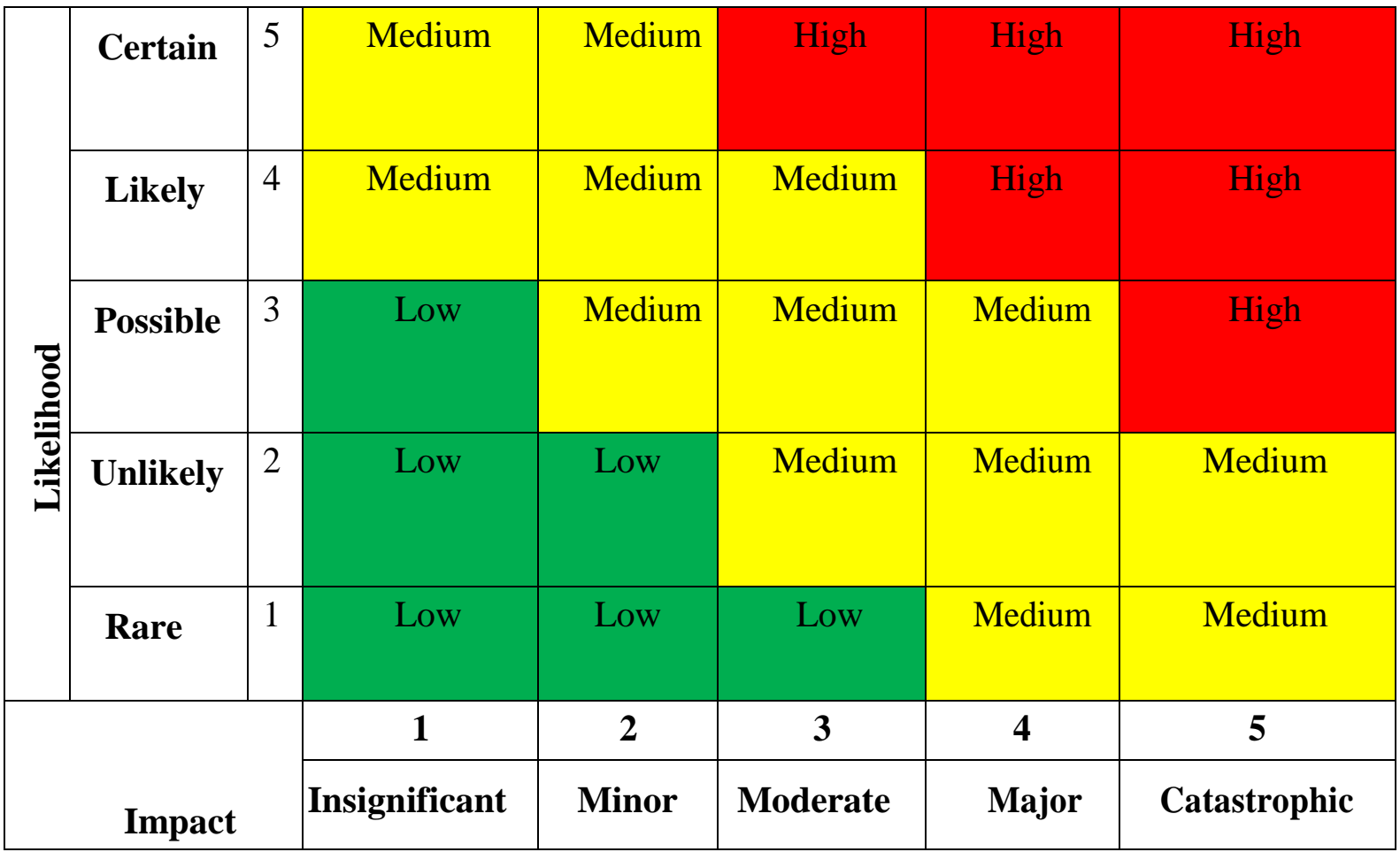

Each possible risk based on likelihood and impact will be entered into the risk evaluation matrix by looking at the mapping in the previous risk evaluation matrix table. In the identity risk evaluation matrix table, each possible risk is entered into parameters according to the likelihood criteria and impact criteria that were carried out previously.

TABLE 8. Risk evaluation matrix based on likelihood and impact

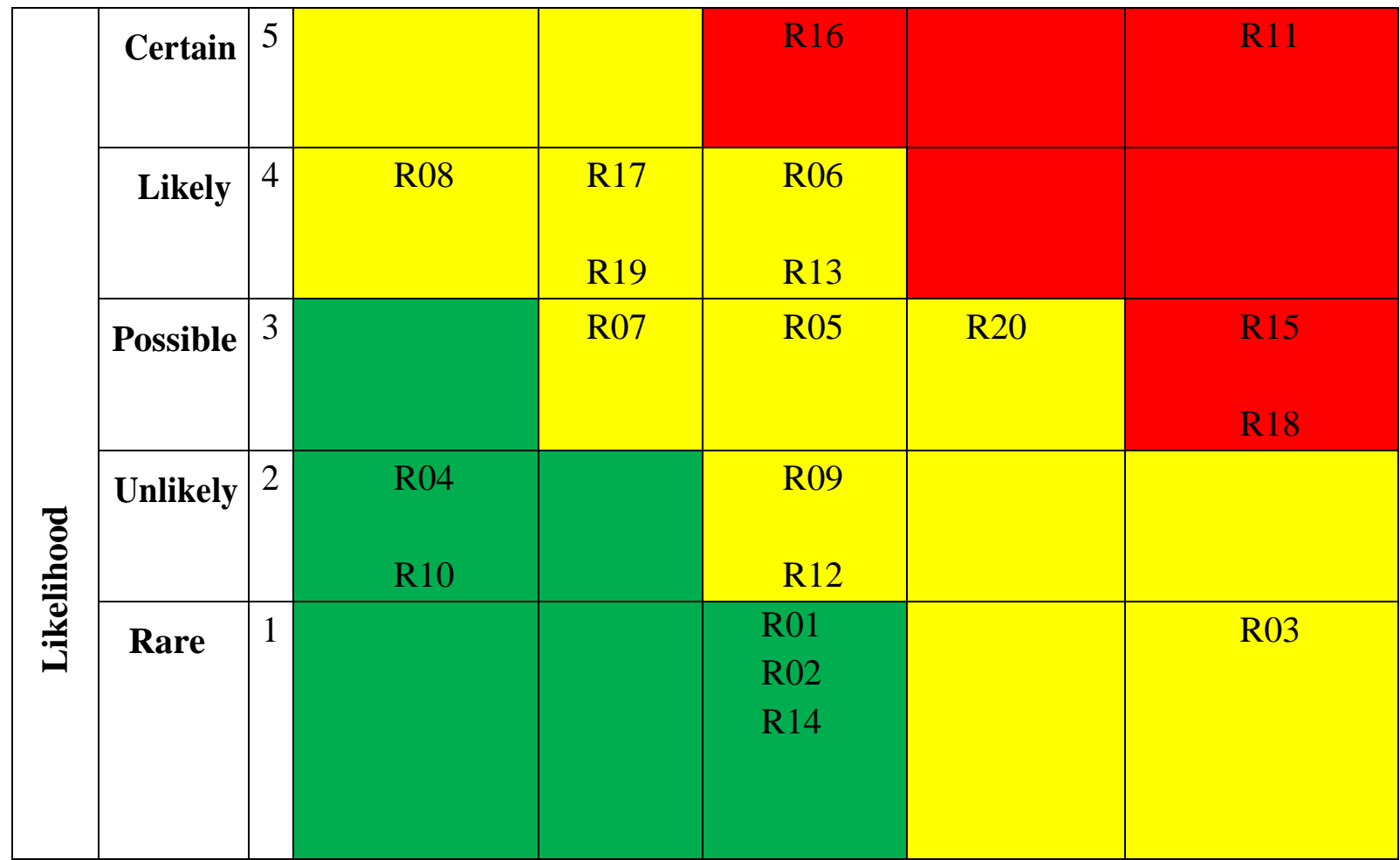




\begin{tabular}{|c|c|c|c|c|c|}
\hline \multirow{3}{*}{ Impact } & 1 & 2 & 3 & 4 & 5 \\
\cline { 2 - 6 } & Insignificant & Minor & Moderate & Major & Catastrophic \\
\hline
\end{tabular}

Then after all the possible risks are entered into the risk evaluation matrix in table 9, it will be described from the 20 possible risks that exist in the BRImo application whether they are included in the level of risk with high, medium or low levels based on likelihood and impact criteria.

TABLE 9. Risk level of possible risks

\begin{tabular}{|c|c|c|c|c|}
\hline $\begin{array}{l}\text { Risk } \\
\text { Code }\end{array}$ & Possible Risk & Likelihood & Impact & Risk Level \\
\hline R01 & Flood & 1 & 2 & Low \\
\hline R02 & Fire & 1 & 2 & Low \\
\hline R03 & Earthquake & 1 & 5 & Medium \\
\hline R04 & Lightning & 2 & 1 & Low \\
\hline R05 & Application can't run & 3 & 3 & Medium \\
\hline R06 & $\begin{array}{l}\text { Damage caused by human } \\
\text { activities (cybercrime and } \\
\text { vandalism) }\end{array}$ & 4 & 3 & Medium \\
\hline R07 & $\begin{array}{l}\text { Information accessed by } \\
\text { unauthorized Parties }\end{array}$ & 3 & 2 & Medium \\
\hline R08 & Error Input data in the application & 4 & 1 & Medium \\
\hline R09 & Device or data theft & 2 & 3 & Medium \\
\hline $\mathrm{R} 10$ & $\begin{array}{l}\text { The appearance of the application } \\
\text { is not user friendly }\end{array}$ & 2 & 1 & Low \\
\hline R11 & Server Down & 5 & 5 & High \\
\hline R12 & Full Memory & 2 & 3 & Medium \\
\hline R13 & Bug In System or Application & 4 & 3 & Medium \\
\hline
\end{tabular}




\begin{tabular}{|c|l|c|c|l|}
\hline R14 & Hacking against the network & 1 & 2 & Low \\
\hline R15 & Virus Attack & 3 & 5 & High \\
\hline R16 & Slow response system performance & 5 & 3 & High \\
\hline R17 & $\begin{array}{l}\text { Error when inputting data in } \\
\text { Application }\end{array}$ & 4 & 2 & Medium \\
\hline R18 & No periodic maintenance & 3 & 5 & High \\
\hline R19 & Logout system automatically & 4 & 2 & Medium \\
\hline R20 & Hardware Damage & 3 & 4 & Medium \\
\hline
\end{tabular}

Based on Table 8 above, it can be seen that from the 20 possible risks identified, there are 4 out of 20 possible risks that have a high level, namely, Server Down, Virus Attacks, Slow system performance responding, and no periodic maintenance Then there are 11 possibilities that have a medium level, namely Earthquakes, Applications cannot be run, Damage caused by human activities (cybercrime and vandalism), Information accessed by unauthorized parties, Data input errors in applications, Device or data theft, Memory Full, System or Application Bugs, Errors when inputting data on applications, System Logout automatically, and Hardware Damage, while the possibility of risk at the Low level has 5 possibilities, namely floods, fires, lightning, the appearance of the application is not user friendly, and network hacking.

\subsection{Risk Treatment}

The stage after risk identification is the risk treatment stage. At this stage, what will be done is to provide suggestions regarding treatment for all possible risks that exist in the BRImo application. The treatment suggestions given are expected to reduce or minimize the possible risks that exist. It can also be used by BRI Bank to prevent possible risks in the BRImo application. Risk treatment is arranged based on the level of risk that has been previously identified, from a high level of risk to a low level of risk, the details of the proposal can be seen in table 10 below.

TABLE 10. Risk Treatment

\begin{tabular}{|c|l|c|l|}
\hline Risk Code & Possible Risk & Level & \multicolumn{1}{c|}{ Risk Treatment } \\
\hline R11 & Server Down & High & $\begin{array}{l}\text { Check in the database and Refresh BRImo } \\
\text { application. }\end{array}$ \\
\hline
\end{tabular}




\begin{tabular}{|c|c|c|c|}
\hline$=$ & \multicolumn{3}{|c|}{$\begin{array}{r}\text { International Journal of information Systems and Informatics } \\
\text { e-ISSN 2746-1378 } \\
\text { Vol. 2, No.4 December } 2021\end{array}$} \\
\hline $\mathrm{R} 15$ & Virus Attack & High & $\begin{array}{l}\text { Install a good and reliable antivirus, limit access } \\
\text { so that not just anyone can access the } \\
\text { application's main database and server }\end{array}$ \\
\hline R16 & $\begin{array}{l}\text { Slow response } \\
\text { system performance }\end{array}$ & High & Refresh the system, check the system regularly \\
\hline $\mathrm{R} 18$ & $\begin{array}{l}\text { No periodic } \\
\text { maintenace }\end{array}$ & High & $\begin{array}{l}\text { There is a need for a regular hardware } \\
\text { maintenance schedule, with a hardware } \\
\text { maintenance schedule, technicians can monitor } \\
\text { which hardware needs to be repaired and } \\
\text { replaced with new hardware }\end{array}$ \\
\hline R03 & Earthquake & Medium & $\begin{array}{l}\text { Provide a backup server in another place / } \\
\text { location that is more secure }\end{array}$ \\
\hline R05 & $\begin{array}{l}\text { Application can't } \\
\text { run }\end{array}$ & Medium & $\begin{array}{l}\text { Immediately make repairs when the application } \\
\text { dies/service and immediately provide } \\
\text { announcements to customers. }\end{array}$ \\
\hline R06 & $\begin{array}{l}\text { Damage caused by } \\
\text { human activities } \\
\text { (cybercrime and } \\
\text { vandalism) }\end{array}$ & Medium & Change server passwords periodically. \\
\hline $\mathrm{R} 07$ & $\begin{array}{l}\text { Information } \\
\text { accessed by } \\
\text { unauthorized } \\
\text { parties }\end{array}$ & Medium & $\begin{array}{l}\text { Conduct regular password maintenance in case } \\
\text { of suspicious things. }\end{array}$ \\
\hline R08 & $\begin{array}{l}\text { Error Input data } \\
\text { in the application }\end{array}$ & Medium & $\begin{array}{l}\text { Correcting errors, providing dataediting features } \\
\text { on the system, checking before running }\end{array}$ \\
\hline R09 & $\begin{array}{l}\text { Device or data } \\
\text { theft }\end{array}$ & Medium & $\begin{array}{l}\text { Correcting errors, providing dataediting features } \\
\text { on the system, checking before running }\end{array}$ \\
\hline $\mathrm{R} 12$ & Full Memory & Medium & $\begin{array}{l}\text { Check memory usage periodically and Increase } \\
\text { memory capacity before it is full. }\end{array}$ \\
\hline $\mathrm{R} 13$ & $\begin{array}{l}\text { Bug In } \\
\text { System or } \\
\text { Application }\end{array}$ & Medium & $\begin{array}{l}\text { Checking the system, conducting periodic } \\
\text { system testing, there is an IT staff in the } \\
\text { ustomer service department who handles } \\
\text { bugs in the system }\end{array}$ \\
\hline
\end{tabular}




\begin{tabular}{|c|c|c|c|}
\hline R17 & $\begin{array}{l}\text { Error when } \\
\text { inputting data in } \\
\text { the application }\end{array}$ & Medium & $\begin{array}{l}\text { Refresh the system if an error occurs when } \\
\text { inputting }\end{array}$ \\
\hline R19 & $\begin{array}{l}\text { Logout system } \\
\text { automatically }\end{array}$ & Medium & $\begin{array}{l}\text { Perform repairs and perform system } \\
\text { performance tests }\end{array}$ \\
\hline $\mathrm{R} 20$ & $\begin{array}{l}\text { Hardware } \\
\text { Damage }\end{array}$ & Medium & $\begin{array}{l}\text { Clean the hardware and immediately report to the } \\
\text { technician if a problematic hardware is found }\end{array}$ \\
\hline R01 & Flood & Low & $\begin{array}{l}\text { Put the server in a place that is difficult to reach } \\
\text { by flooding (at higher ground), Have a backup } \\
\text { server in a different place }\end{array}$ \\
\hline $\mathrm{R} 02$ & Fire & Low & Installing a backup server in a different location \\
\hline R04 & Lightning & Low & $\begin{array}{l}\text { Installing a lightning rod, Automatically } \\
\text { backing up the main server into the backup } \\
\text { server }\end{array}$ \\
\hline R10 & $\begin{array}{l}\text { The appearance of } \\
\text { the application is } \\
\text { not user Friendly }\end{array}$ & Low & $\begin{array}{l}\text { Make improvements by changing the user } \\
\text { interface of the application that is easy to } \\
\text { understand with the right color selection }\end{array}$ \\
\hline R14 & $\begin{array}{l}\text { Hacking against } \\
\text { the network }\end{array}$ & Low & $\begin{array}{l}\text { Set complex passwords for every important part } \\
\text { of the app }\end{array}$ \\
\hline
\end{tabular}

\section{Conclusion}

The stages of risk management analysis on the BRImo application at BRI banks based on the International Organization for Standardization (ISO 31000:2009) have been carried out. The risk analysis process is carried out from the risk assessment stage through 3 steps, namely risk identification, risk analysis, and risk evaluation. And the risk treatment stage is to make suggestions for risk treatment for the possible risks that exist in the BRImo application.

From the results of the risk analysis, it can be seen that there are 20 possible risks that have the potential to disrupt the performance of the BRImo application. There are 4 possible risks that are included in the level of risk high out of 20 possibilities, namely, Server Down, Virus Attacks, System performance that is slow to respond, and no periodic maintenance. Then there are 11 possibilities that are included in the medium level of risk, namely Earthquakes, Applications cannot be run, Damage due to human activities (cybercrime and vandalism), Information accessed by unauthorized parties, Errors in data input in applications, Theft of devices or data, Full Memory, System or Application Bugs, Errors when inputting data on applications, System Logout automatically, and Hardware Errors. there are 5 possible risks that are included in the low level of risk, namely flood, fire, lightning, the appearance of the application is not user

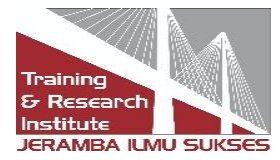


friendly, and network hacking

From the results obtained, it can be seen that in overcoming the possible risks that exist in Bank BRI, BRI has implemented steps to minimize the impact of possible risks that often occur, but for system error problems, Bank BRI can monitor and perform regular maintenance on the BRImo application so that system error problems and possible risks can be minimized and business processes can run well.

\section{References}

1. Ayani, D. H. (2019). Berapa Pengguna Internet di Indonesia? Retrieved January 2, 2020, from https://databoks.katadata.co.id / datapublish/2019/09/09/berapa-pengguna-internetdi- indonesia

2. BRI BANK, www.bri.co.id, accessed on 21 August 2021 at 20.30

3. Z. Putra, S. Chan, and M. IHA. 2018, Desain Manajemen Risiko Berbasis ISO 31000 pada PDAM Tirta Meulaboh, E-Kombis, Vol. 3, No. 1, pp. 52 - 71.

4. G. W. Lantang, A. D. Cahyono, and N. Ngalumsine, 2019, Analisis Risiko Teknologi Informasi pada Aplikasi SAP di PT Serasi Autoraya Menggunakan ISO 31000, Sebatik 2621- 069X, Vol. 23 No. 1, pp. 36-43

5. A.Rahmawati and A. F. Wijaya, "Analisis Risiko Teknologi Informasi Menggunakan ISO 31000 pada Aplikasi ITOP,” J. SITECH Sist. Inf. dan Teknol., Vol. 2, No. 1, pp. 13-20, 2019, doi: 10.24176/sitech.v2i1.3122.

6. S. Agustinus, A. Nugroho, and A. D. Cahyono, "Analisis Risiko Teknologi Informasi Menggunakan ISO 31000 pada Program HRMS,” J. RESTI (Rekayasa Sist. dan Teknol. Informasi), Vol. 1, No. 3, pp. 250-258, 2017, doi: 10.29207/resti.v1i3.94.

7. Z. Putra, S. Chan, and M. IHA. 2018, Desain Manajemen Risiko Berbasis ISO 31000 pada PDAM Tirta Meulaboh, E-Kombis, Vol. 3, No. 1, pp. 52 - 71.

8. Qintharah, Y. N. 2019. 'Perancangan Penerapan Manajemen Risiko (Studi Kasus Pada Umkm Saripakuan CV. Jarwal Maega Buana)', JRAK, 10(1), pp. 67-86. Available at: jurnal.unismabekasi.ac.id/index.php/jrak/article/download/1645/1420/\%0A\%0A.

\section{Copyrights}

Copyright for this article is retained by the author(s), with first publication rights granted to the journal.

This is an open-access article distributed under the terms and conditions of the Creative Commons Attribution license (http://creativecommons.org/licenses/by/4.0/) 